OPEN ACCESS

Vol. 6, No. 2, October, 2018

Page. 57 - 70
JOURNAL OF AUDITING, FINANCE, AND FORENSIC ACCOUNTING (JAFFA)

E-ISSN: 2461-0607

ISSN: $2339-2886$

\title{
THE BUSINESS OWNERS SMES SECTOR OF INTENTION TO USE THE SEVICES BY EXTERNAL ACCOUNTANTS
}

Irwansyah; Madani Hatta; Ghulam Ferdi Al Masriki

Accounting Department, Faculty of Economics and Business, University of Bengkulu

Article Info:

Received: 5 November 2018

in revised form: 14 November 2018

Accepted: 30 November 2018

Available Online: 12 December 2018

\section{Keywords:}

Perception of the business owners SMEs sector of intention, use the service by external accountants

Corresponding Author: Email: onesyah2000@yahoo.com; manadi.unib2006@gmail.com

\begin{abstract}
This study aimed to prove attitude toward behavior, subjective norm, perceived behavioral control, perception of the business owners SMEs sector about competence of the accountant external, size of business, and competitive industries has positive effect on the intention to use the services from external accountants. Respondents in this study were 67 business owners in SMEs sector in Bengkulu city. The method of collecting data in this study using a survey by questionnaires to the respondents either directly. The data was analyzed by using SmartPLS 3.O. The result show that attitude toward behavior, subjective norm, perceived behavioral control, external accountant to be competent, size of business, and competitive industries has positive effect on intention to use the services from external accountants
\end{abstract}

Abstrak; Penelitian ini bertujuan untuk membuktikan pengaruh sikap pada perilaku, norma subyektif, persepsi kontrol perilaku, persepsi pemilik usaha UKM sektor tentang kompetensi akuntan eksternal, ukuran bisnis, dan industri kompetitif berpengaruh positif terhadap niat menggunakan jasa dari akuntan eksternal. Responden dalam penelitian ini adalah 67 pemilik usaha di sektor UKM di Kota Bengkulu. Metode pengumpulan data dalam penelitian ini menggunakan survei dengan menyebarkan kuesioner kepada responden secara langsung. Analisis data menggunakan SmartPLS 3.0. Hasil penelitian membuktikan bahwa sikap terhadap perilaku, norma subyektif, kontrol perilaku yang dirasakan, akuntan eksternal untuk menjadi kompeten, ukuran bisnis, dan industri kompetitif memiliki efek positif pada niat untuk menggunakan layanan dari akuntan eksternal 


\section{INTRODUCTION}

Small and Medium enterprises (SMEs) is one of the movers in the Indonesian economy. The role of Small and Medium Enterprises (SMEs) in Indonesia's economy most can not be seen from (1) its position as a major player in economic activities in various sectors, (2) a provider of employment the largest, (3) important players in the development of local economic activity and community empowerment, (4) the creator of a new market and source of innovation, and (5) contributions in maintaining the balance of payments through export activities (Raselawati, 2011).

In general, SMEs face a variety of problems that occur in running its operational activities. According to research conducted by Urata (2000) in Adawiyah (2013) there are factors that can cause problems of SMES, such as related to business loan to the lenders. The government has designed the program of financing of SME (Micro, Small, and Medium), one such program is the People's Business Credit (KUR) in the year 2017 targeted around Rp 110 Trillion (Policy Agricultural Finance, 2017). The purpose of the KUR is to be a solution to capital financing which is effective for SMEs.

According to research conducted Baas and Schrooten (2006) in Rudiatoro and Siregar (2012) causes of the low KUR such as a bank appointed as dealer of KUR are very cautious in lending, because they do not get adequate information regarding the condition of SMEs. The majority of SME entrepreneurs are not able to provide accounting information regarding the condition of its business.

The research conducted by Said (2009) in Rudiatoro and Siregar (2012) explain the factors that affect the inability of the SMEs in providing accounting information related to its business, such as limited knowledge about accounting, the complexity of the accounting process, and the presumption that the financial statements are not things that are important to SMEs are all factors that can lead to the difficulty of SMEs in doing bookkeeping. In fact the function of the financial report itself is very important for the progress of the business, including the financial statements can be useful to obtain credit approval from the bank, reporting of business tax, and internal purposes of the company.

Before certify the SAK EMKM, the Financial Accounting Standards Board Indonesian institute of Accountants (DSAK IAI) which is the competent authorities in compiling accounting Standards in Indonesia have been previously doing research on the needs of the SAK EMKM. Then draw up a draft, hold a public hearing with stakeholders, and endorsed the Exposure draft in 2016. Finally after going through two processes, the DSAK IAI set SAK EMKM effective for the preparation of financial statements EMKM beginning on or after January 1, 2018 (manajemenpraktis.com 28/9/2017, accessed 4 November 2017). Therefore, on January 1, 2018, it is hoped that SMES have been able to implement a system of recording and making financial reports according to the standard EMKM that had been developed by the IAI, so that later can become the basis in decision-making, both from a strategic decision made by management and decisions by other parties such as the banks, financial institutions, and others.

The accounting profession externally in the world of business has long been providing services such as service specialized tax, audit, and others. Services designed aims to meet regulatory requirements or to satisfy applicable law. According to Camegle and Napler (2009), in Carey (2016) accountant external described as "business professional" that focuses on adding business value and support the needs of the client changed, so the need for the services of the accountant external to the attention in the world of business today. This is supported by the research of Blackburn and Jarvis (2010), their research shows that in London, accountant external is most often used as a source of professional services in the SME.

Theory of Planned Behavior (TPB) is a model that is common to used in view of the factors that can influence the decisions and behavior of someone (Endah, 2014). Based on this theory, one's intention is influenced by three factors namely: Attitude toward behavior, subjective Norm, Perceived behavioral control.

According to Carey (2016), factors that affect the accountant needs external competence, the risk of financial effort which is measured by using the indicator of the ratio of the gearing, the age of the business or the age of the business, business losses (loss), and the last Factor that affects the needs of the accountant external by the owner 
of the business the SME sector, namely the competitive industry or the competitiveness of the industry.

This research wants to re-test conducted by Carey (2016) with the object of research business owner of the SME sector in the City of Bengkulu are not using the services of the accountant external. The difference of this research with previous research is that previous research using the approach of Theory Agency with the variables competence, financial risk is measured using the age of the business, the ratio of the gearing, and business losses in the previous year, and the industry competitive against the provision of business advice to SMES by the accountants external, whereas in this study using the approach of Theory of Planned Behavior (TPB) where the researcher wants to know the intentions of the business owner of the SME sector to use the services of the accountant external.

The variables used in this study are the variables in the Theory of Planned Behavior (TPB), namely attitude toward behavior, subjective norm, perceived behavioral control and the variables used by previous research, namely the competence of the accountant external, the size of the business, and the variables of competitive industries or the competitiveness of the industry. The size of the business to be variable because the bigger a business it will result in business transactions has increased and will likely experience recording errors and the more business owners the SME sector requires the services of an accountant external.

This is supported by research conducted Wicaksono (2015), which concluded that enterprise size has a positive effect on the perception of the businesses about the importance of financial reporting under the financial accounting standards.

\section{LITERATURE REVIEW AND HYPOTHESES DEVELOPMENT}

\section{Theory of Planned Behavior}

Theory of Planned Behavior (TPB) is an extension of the Theory of Reaction Action (TRA) where TPB is designed to predict and explain human behavior in a specific context (Ajzen, 1991). In the TPB stated that the decision to display a certain behavior is a rational process directed at a particular goal and follow the sequence of thought. The choice behavior to be considered, the consequences and the outcome of each behavior is evaluated, and made a decision whether to act or not (Freciana, 2013), then the decision is reflected in the purpose of the behavior, and can be a predictor to how we will behave in situations that occur (Ajzen, 1991).

According to Freciana (2013), behavior is determined by motivation (motivation) and ability (ability), where is the motivation or intention of leads on the level or levels of a specific action shown by someone. In theory the behavior of a well-planned (Theory of Planned Behavior), the main factor of a behavior that displayed the individual is the intention (intention) to display a certain behavior (Ajzen, 1991).

Figure 1 Theory of Planned Behavior

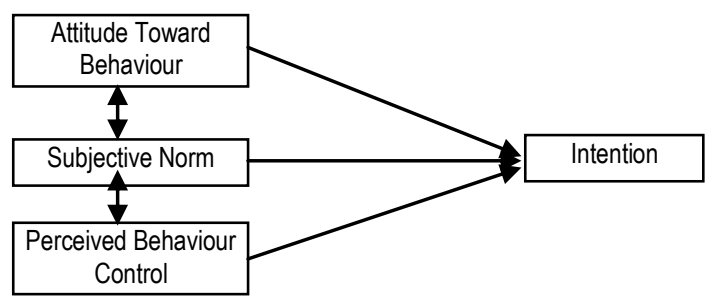

Source: Theory of Planned Behavior, Ajzen (1991).

Intention is assumed as a factor of motivational influence behavior. Intention is an indication of how hard someone tries or how much effort is made to display a behavior (Rois, 2016). According to Ajzen (1991) in Asmarandani (2017), the harder a person's intention to engage in a behavior, the greater the tendency of a person actually perform the behavior. The intention to behave can be actual behavior only if the behavior were 
under the control of the individual concerned. Individuals have the choice to decide on a certain behavior or not at all.

\section{The Development of the Hypothesis \\ Attitude Toward Behavior and the Intention to Use the Services of the Accountant External}

Yogatama (2013) defines attitude toward the behavior (Attitude Toward Behavior) as the evaluation and the tendency of someone to react or respond toward an object of attitude. The object of the attitude can be objects, events, people, phenomena, or other things. Attitude determines the assessment of a person to like or dislike (favorableunfavorable) towards the object of attitude. In the research Rahmadanty (2015) proved that the attitude has a positive effect on intention.

The individual will have two possibilities, i.e. have a positive attitude towards their intention in using the services of the accountant external or have a negative attitude related to their intention in using the services of the accountant external. When the owner of the business sector SMEs use the services of the accountant external, they acquire advantage of this when the accountant external to assist in the activities of the business especially in the field of administration and will result in a decision to use the services of the accountant external, but for some business owners the SME sector when using the services of the accountant external it could be something that is not useful, resulting in decisions that do not use the services of the accountant external, therefore the first hypothesis, namely:

$\mathrm{H}_{1}$ : Attitude toward behavior has positive influence on the intention of the owner of the

business sector SMEs in using the services of the accountant external.

\section{Subjective norms and Intentions to Use the Services of the Accountant External}

According to Fishbein and Ajzen (2005) in Mulya (2009), subjective norm is defined as the perception of a person will be social pressure to show or not show the behavior with a certain consideration. Social pressure comes from people around that are important to him (significant others). Research Asmarandani (2017) concluded that subjective norms are formed from pressure in the environment around the individual and the need to be accepted by the people who followed the norms subjective, to encourage purchase intention.

The pressure comes from the business environment, both from internal as family and business associates and is derived from the external such as pressure from government and creditors, which requires that business owners of small and medium enterprises to provide financial information accountability will have an impact on decisions that will affect the intention of the owner of the business sector SMEs to use the services of the accountant external, therefore the second hypothesis, namely:

$\mathrm{H}_{2}$ : Subjective Norm has a positive effect on the intention of the owner of the business sector SMES in using the services of the accountant external.

\section{Perceived Behavioral Control and Intention to Use the Services of the Accountant External}

Ajzen (1991) defines perceived behavior control or behavior control perceived refers to the perception of a person against difficult whether or not to carry out the desired behavior, associated with confidence will be available whether or not the resources and opportunities necessary to realize a certain behavior to reflect the past experiences and the anticipation of barriers and obstacles.

Research Mustikasari (2007) proved that perceived behavioral control has a positive effect on the intention to behave. When the greater the ability, opportunity, and control of the business owner of the SME sector to use the services of the accountant external, then the owner of the business the SME sector that will feel the little obstacles and the opportunity to perform the action is greater, so that it is able to improve the intention of the owner of the business sector SMEs in using the services of the accountant external, therefore the third hypothesis, namely:

$\mathrm{H}_{3}$ : Perceived behavioral control has a positive effect on the intention of the owner of the business sector SMEs in using the services of the accountant external. 
The perception of Owners of Business SME about the Competence of An Accountant External and Intention to Use the Services of the Accountant External

Competence related to skill (skill), knowledge (knowledge), and attitude (attitude and behavior) offered owned by an accountant. Research Carey (2016) concluded that SMEs are more likely to buy business advice from Accountants when they believe the expertise and knowledge of the Accountant External, it is supported by research conducted Gooderham et al. (2014) who reported that the competence of the accountant is the most decisive with the significant extent to which small firms use accountants external them as business advisors.

In running the business, often owner/ managers of small and medium enterprises (SMEs) feel difficulty in doing the recording of what happens on the operational business. This difficulty concerning the activity and assessment of the results achieved by each business. Moreover, to do the measurement and assessment of activities that occur in business activities. Most small and medium businesses (SMEs) only count property that is owned to the extent of cash held. They do not understand that the definition of treasure is more widespread than just money in the form of cash (Suryo, 2006), therefore the fourth hypothesis, namely:

$\mathrm{H}_{4}$ : The Perception of owners of business SME about the competence of an accountant external positive influence on the intention of the owner of the business sector SMEs in using the services of the accountant external.

\section{The perception of Owners of Business SME about the Size of the Business and the Intention to Use the Services of the Accountant External.}

In the research Wicaksono (2016) the variable size of the business affect the perception of businesses about the importance of financial reporting based on SAK ETAP. The size of the business is determined by the amount of sales made by the company in each year.

The greater the number of sales that can be obtained effort the greater the size of the business, the greater the size of the company, it will result in increasingly complex transactions faced by the company, the greater the financial transactions that take place and will be frequent errors in the recording of transactions, accounting data and financial statements so that it will lead to increased demand for accounting services external the decision to use the services of the accountant external will semain large and will affect the intention of the owner of the business sector SMEs in using the services of the accountant external, therefore the fifth hypothesis, namely:

$\mathrm{H}_{5}$ : The Perception of owners of business SME about the size of enterprises has a positive effect on the intention of the owner of the business sector SMEs in using the services of the accountant

\section{The perception of Owners of Business SME about Competitive Industries and the} Intention to Use the Services of the Accountant External.

The competition is the core of the success or failure of the company. There are two sides to that posed by the competition, namely the side's success because it encourages companies to be more dynamic and vie is regarded as the opportunities that motivate, while the other side is a failure because it will weaken the company-a company that is static, the fear of competition and is not able to produce quality products, so the competition is a threat for the company.

Research conducted Carey (2016) concluded that competitive (competition) business has a positive effect on purchase business advice from Accountants External. In a competition in the business world, a company must have enough strategy in order to survive in the competition. One of the strategies that must be considered by the company include the aspect of capital. From some of the problems faced by the company, the problem of capital is a classic problem faced by UKM (Lestari, 2010). By utilizing the quality of financial reporting and accountable, of course, the need of the services of the accountant external to be important in the world of business and with financial reports prepared is expected to help the management in making a strategic decision, so that the company can overcome the problems especially in the aspect of capital. Thus, the fourth hypothesis, namely: 
$\mathrm{H}_{6}$ : The Perception of business owners of small and medium enterprises for Competitive Industries has a positive effect on the intention of the owner of the business sector SMEs in using the services of the accountant external.

\section{RESEARCH METHODOLOGY}

Research type in this research is quantitative. Data collection using research instruments, data analysis, and is quantitative with the aim to test the hypothesis that has been set.

The variables used in this study are latent variables, latent variables, namely endogenous and exogenous, exogenous Variables in this study consisted of attitude toward behavioral, subjective norm, perceived behavioral control, the competence of the accountant external, the size of the business, the industry competitive. While the endogenous variable in this study is the intention in using the services of the accountant external.

Variables attitude toward behavioral measured by the dimensions of the passions against the idea of using the services of an accountant external, the response of using the services of the accountant external interest in the use of the services of the accountant external, the view between business and accounting services external.

a. The variable subjective norm is measured by the perceptions regarding social pressure from the people that influence people's decisions, perceptions regarding social pressure from the people who play an important role in life, a response to the influence of the people who was instrumental in using the services of the accountant external.

b. The variable perceived behavioral control was measured with the dimensions of ease in using the services of the accountant external, control in using the services of the accountant external, the ability to use the services of the accountant external.

c. Variable competence of the accountant external measured with the dimensions of knowledge on SAK EMKM, the importance of the services of the Accountant External in the business, increase the effectiveness of the effort, trust accountant external.

d. The variable size of the business measured by the dimension of the number of employees, net worth, results of annual sales.

e. Variables of the competitive industry is measured by the dimensions of the strong competition, the key to success, competitive advantage.

f. Variable intention to use the services of the accountant external how strong is the desire of the individual to display a behavior and how much effort that is planned or done by an individual to perform the behavior. Variable intention to use the services of the accountant external measured with the dimensions of intention to use the services of the accountant external, try to use the services of the accountant external, has no intention to use the services of the accountant external because not need it.

Population and sample this research is the small and medium enterprises (SMEs) that are registered in Department of Cooperatives and SMES of the City of Bengkulu 2017. The selection of the sample of small and medium enterprises (SMEs) due to this business must prepare financial statements in accordance with accounting standards that have been established, namely the Financial Accounting Standards Entities Micro, Small and Medium enterprises (SAK EMKM). Sampling was done by purposive sampling method. To obtain sample according to specified criteria as follows:1) SMEs which have a net worth (excluding land and buildings, places of business) of more than Rp 50.0000 .000 (fifty million rupiah) and at most Rp 10.000.000.000 (ten billion rupiah); 2) SMEs that have annual sales of more than $\mathrm{Rp} 300.000 .000$ (three hundred million rupiah) and at most Rp 50.000.000.000 (fifty billion); 3) SMEs have been operating for at least 1 year.

The Data used in this research is primary data. Data obtained through the questionnaire by the respondents, data collection techniques for this questionnaire is to provide a set of statements to the respondents.

Data analysis in this research using the approach of Partial Least Square (PLS). PLS is defined by two equations, namely the inner model and outer model. The Inner model specifies the specification of the relationship between the constract and constract 
another, whereas the outer model specifies the specification of the relationship between the constract and the indicators. Outer Model (Measurement Model) is used to determine the validity and reliability of connecting the indicators with the construct or the latent variables. Testing the inner model or outer model structural done to see the relationship between the constructs, the value of significance and R-square of the research model.

Hypothesis testing is done by the process of bootstrapping/ resampling bootstrapping. Testing the hypothesis can be seen from the magnitude of the value of the significance P-value and $t$-value statistics. The criteria for rejecting and accepting the relationship asked can be seen from the value of P-value $<0.05$, and the comparison between the value of t-statistics and the t-table. If the value of t-statistics $>\mathrm{t}$-table $(2,00)$ then the hypothesis is accepted (Ghozali, 2014).

\section{FINDINGS AND DISCUSSION}

The number of questionnaires distributed a total 67 copies, and the total questionnaires returned and can be used as much as 67 copies. Data collection in this research, to disseminate directly, a questionnaire distributed by way of delivering directly to the respondents, supplemented with an interview or oral questions, it is anticipate the occurrence of the difference pesepsi between authors with the respondents, having filled the questionnaire directly collected and then processed to find the results of the study. The time required for the collection of data for 26 days, from the date of January 3rd, 2018 to January 29th, 2018.

This study uses structural equation models in the analysis by using SmartPLS, then conducted the evaluation of the outer model using PLS Algorithm.

Figure 2 The Research Model

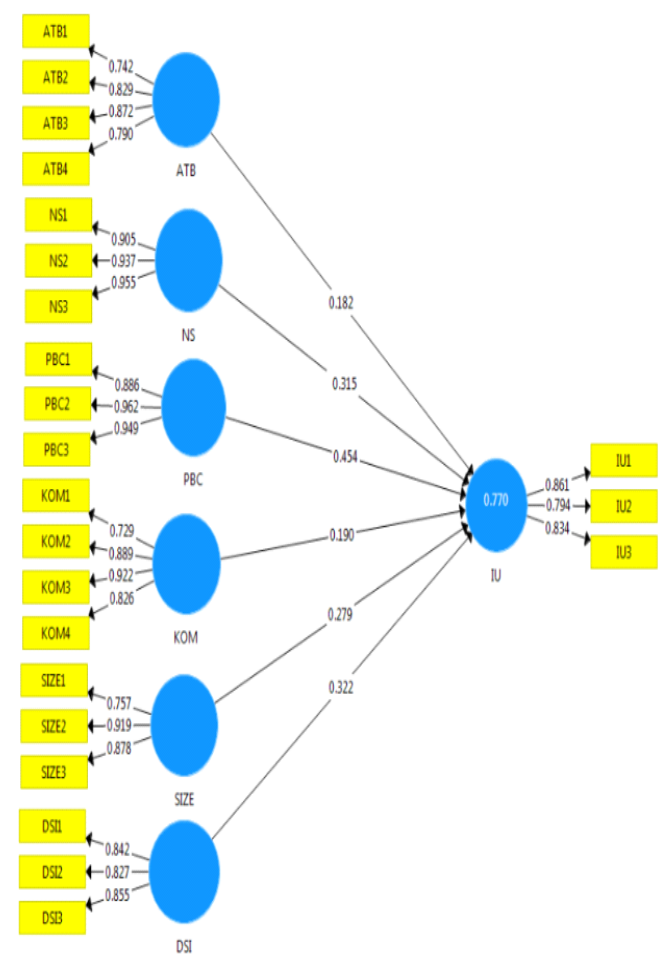

Source: Data processing with SmartPLS 3, 2018.

Figure 3 Display the Results of the PLS Algorithm

Based on figure 2 shows, the results of the calculation of the outer loading for all indicators that form the construct/ variables of the research have correlation values above the 0.70 , which means the indicators of a construct has validity. 
The value of cross loading also showed discriminant validity is good because the value of the correlation indicators to konstruknya higher than the value of the correlation indicators with other constructs. The results of the validity test convergent measured by looking at the score Average Variance Extracted (AVE). From the output of SmartPLS above all the constructs have a value of AVE is above 0.50 for all constructs, which means that the construct has validity konvergan good.

In addition to the test of construct validity, also performed the reliability test of the constructs measured by the composite reliability and cronbach's alpha of the block of indicators that measure the constructs. From the results of SmartPLS above all the constructs have a value of composite reliability above 0.70 and cronbach's alpha above 0,60 , so it can be concluded that the constructs have good reliability and meet the criteria of reliability test.

After the model is estimated to meet the criteria of discriminant validity of subsequent testing of the structural model (inner model). Assessing the inner model is to see the relationship between the latent construct to see the results of the estimation coefficient parameter the path and the level of significance (Ghozali, 2008).

Table 1. R-Square

\begin{tabular}{lc}
\hline \multicolumn{1}{c}{ Variable } & R-Square \\
\hline IU (Intention to Use the Services Of the & 0,770 \\
Accountant External) & Source: Data processing with SmartPLS 3, 2018.
\end{tabular}

In Table 1 shows that the value of R-Square of this study there is one variable that is affected by other variables variable's intention to use the services of the accountant external that are affected by the variable attitude toward behavior, subjective norm, perceived behavioral control's, the competence of the accountant external, the size of the business, and the industry competitive. On the variable intention to use the services of the accountant external influence of 0,770 of attitude toward behavior, subjective norm, perceived behavioral control, the competence of the accountant external, the size of the business, and the industry is competitive which means that the influence of latent independent amounting to $77 \%$ while $33 \%$ is influenced by other variables outside the research model.

In the PLS testing of statistically every relationship hypothesized is done comparing the value of $t$-statistic with the t-table of significance of $a=5 \%(2,00)$ shown in Table 2 below:

Table 2. Path Coefficient

\begin{tabular}{lccc}
\hline & OriginalSample (O) & T- Statistics (O/STDEV) & P Values \\
\hline ATB > IU & 0,182 & 2,449 & 0,015 \\
NS > IU & 0,315 & 2,479 & 0,014 \\
PBC > IU & 0,454 & 3,197 & 0,002 \\
KOM > IU & 0,190 & 2,038 & 0,042 \\
SIZE > IU & 0,279 & 3,379 & 0.001 \\
DSI > IU & 0,332 & 3,478 & 0,001 \\
\hline
\end{tabular}

Source: Data processing with SmartPLS 3, 2018.

Table 2 shows that the value of the coefficient between attitude toward behavior (ATB) with the intention of using the services of the accountant external (IU) of 0,182, the results of the t-statistic $(2,449)>t$-table $(2,00)$, and the value of $p$-value by 0.015 . This suggests that the variable attitude toward behavior (ATB) proved a positive influence on the intention to use the services of the accountant external (IU), thus hypothesis 1 in this study received.

The value of coefficient between subjective norms (NS) with the intention of using the services of the accountant external (IU) equal to 0,315, the results of the t-statistic $(2,479)>t$-table $(2,00)$, and the value of the p-value of 0.014 . This shows that the variables of subjective norm (NS) proven positive effect on the intention to use the services of the accountant external (IU), thus hypothesis 2 in this study received.

The value of the coefficient between perceived behavioral control (PBC) with the 
intention of using the services of the accountant external (IU) of 0,454, the results of the $\mathrm{t}$-statistic $(3,197)>\mathrm{t}$-table $(2,00)$, and the value of the $\mathrm{p}$-value of 0.002 . This shows that the variable perceived behavioral control $(\mathrm{PBC})$ proved to be a positive influence on the intention to use the services of the accountant external (IU), thus hypothesis 3 in this study received.

The value of the coefficient between the competence of the accountant external (KOM) with the intention of using the services of the accountant external (IU) of 0,190, the results of the $\mathrm{t}$-statistic $(2,038)>\mathrm{t}$-table $(2,00)$, and the value of the $\mathrm{p}$-value of 0,042 . This shows that the variable competence of the accountant external (OMC) proved a positive influence on the intention to use the services of the accountant external (IU), thus hypothesis 4 in this study received.

The value of the coefficient between the size of efforts (SIZE) with the intention of using the services of the accountant external (IU) of 0,279 , the results of the t-statistic $(3,379)>t$-table $(2,00)$, and the value of the $p$-value of 0.001 . This suggests that the variable size of the business $(\mathrm{KOM})$ proved a positive influence on the intention to use the services of the accountant external (IU), thus hypothesis 5 in this study received.

The value of the coefficient between the competitive industries (DSI) with the intention of using the services of the accountant external (IU) of 0,322, the results of the $\mathrm{t}$-statistic $(3,478)>t$-table $(2,00)$, and the value of the $p$-value of 0.001 . This shows that the variable of competitive industries (DSI) proved a positive influence on the intention to use the services of the accountant external (IU), thus hypothesis 6 in this study received.

\section{Attitude Toward Behavior and the Intention to Use the Services of the Accountant External.}

The first hypothesis stated that attitude toward behavior has positive influence on the intention of the owner of the business sector SMEs in using the services of the accountant external, empirically proven to be supported. The results of this study support the Theory of Planned Behavior which states that attitude toward behavior is one of the determining factors of the intention to perform a behavior.

The results of this testing proved that the attitude toward behavior has influence of the belief that when the owner of the SMEs use the services of the accountant external, they feel the benefits obtained, it is felt that using the services of the accountant external is a good idea, and will give you a smooth for the survival of their businesses.

The results on the first hypothesis supports the study of Kim et al. (2013) in Rahmadanty (2015) and Asmarandani (2017) who found that attitude toward behavior has positive influence on intention. Rahmadanty (2015) conclude that when the majority of the members of the community have a positive response to an idea to use the savings of sharia. They have a positive evaluation thoroughly and have an attitude of attraction towards the use of islamic savings so that they have the intention to behave that behavior using islamic savings.

\section{Subjective norms and Intentions to Use the Services of the Accountant External.}

The second hypothesis stated that the subjective norm has a positive effect on the intention of the owner of the business sector SMEs in using the services of the accountant external, empirically proven to be supported.

The results of this testing proved that subjective norm has an influence on the intention of the owners of SMEs to use the services of the accountant external, it is explained that individuals get the support from the people important and co-workers who want to use the services of the accountant external, so it can help the SME owners in the smooth running of their business.

The results on the second hypothesis supports the research this research supports the Research Asmarandani (2017) who found that support from those closest to the perceived positive effect on a person's behavior. In his research, Asmarandani explain the subjective norm is formed from the pressure in the environment around the individual and the need to be accepted by the people who followed the norm of subjective, able to push the intention. 


\section{Perceived Behavioral Control and Intention to Use the Services of the Accountant External.}

The third hypothesis states that perceived behavioral control has a positive effect on the intention of the owner of the business sector SMEs in using the services of the accountant external, empirically proven to be supported. The results of this testing proved that perceived behavioral control has a positive effect on the intention of the owner of the business sector SMEs in using the services of the accountant external, an individual has a perception of ease to use the services of the accountant external, such as consider using the services of the accountant external is easy and can be done, when there is the experience of the support and the presence of supporting infrastructure and facilities, so the ease in using the services of the accountant external can be done.

The result on the third hypothesis supports the research Asmarandani (2015), Lisnawati (2015) and Mustikasari (2007) proved that perceived behavioral control has a positive effect on the intention to behave. people who believe that they do not have the resources and opportunity to do certain behaviors, may not form the intentionbehavioral intention strong to do it, because they feel the barriers to achieving these actions, although they have a positive attitude toward the behavior and believe that other people would approve of if they do such behavior. However on the contrary if they have the resources to perform the behavior, then intention to perform a certain behavior will be even greater.

\section{The perception of Owners of Business SME about Competence of the Accountant External and Intention to Use the Services of the Accountant External.}

The fourth hypothesis stated that the perception of owners of business SME about the competence of the accountant external positive influence on the intention of the owner of the business sector SMEs in using the services of the accountant external empirically proved acceptable.

This is in accordance with the answers of respondents on average answer score of 3 which means this indicates on average respondents have a lack of knowledge on SAK EMKM, in addition accountant external can help improve the effectiveness business, so that it is able to encourage SME owners to use the services of the accountant external. The results of this study support the research conducted by Carey (2016), which proves that the competence has a positive relationship to purchase business advice from accountants external.

\section{The perception of Owners of Business SME about the Size of the Business and the Intention to Use the Services of the Accountant External.}

The fifth hypothesis stated that the perception of owners of business SME about the size of enterprises has a positive effect on the intention of the owner of the business sector SMEs in using the services of the accountant external, empirically proven acceptable.

This shows that the respondents have a size of business that is small but they have enough resources to use the services of the accountant external assessed from the number of employees, the amount of the net assets (other than land and buildings), and the results of the annual sales of the business.

The results of this study support the research conducted by Abrams (2016) and Gooderham et al. (2004) prove that the size of the business have a positive relationship to the needs of SAK ETAP for SMEs and the needs of accountants as sources of business advice for small companies. This is due to the size of the business can influence the thinking of businessmen associated with the complexity and increasingly high levels of corporate transactions.

\section{The perception of Business Owners the SME Sector of the Industry is Competitive and the Intention to Use the Services of the Accountant External.}

Hypothesis the sixth stated that the perception of owners of business SME about the competence of the accountant external positive influence on the intention of the owner of the business sector SMEs in using the services of the accountant external proven supported. This indicates that the industry competitive have an influence in encouraging the intention of the owner of the business sector SMES to use the services 
of the accountant external, one of the strategies that must be considered by business include the aspect of capital By utilizing the quality of financial reporting and accountable, of course, the need of the services of the accountant external to be important in the world of business and with financial reports prepared is expected to help the management in making a strategic decision, so that the company can overcome the problems especially in the aspect of capital.

The results on the hypothesis the sixth supporting research Carey (2016) and Gooderham et al. (2004). The results of this study in accordance with the statements of Bennett and Robson (2006) explains that the Accountant External can help in maintaining the competitive advantage of SMEs. In a competition in the business world, a company must have enough strategy in order to survive in the competition.

\section{CONCLUSION AND SUGGESTIONS}

Based on the results of the discussion it can be concluded as follows:

1. Attitude toward a behavior proven to be a positive influence on the intention of the owner of the business sector SMEs in using the services of the accountant external.

2. Subjective norm proved a positive influence on the intention of the owner of the business sector SMEs in using the services of the accountant external.

3. Perceived behavior control proven positive effect on the intention of the owner of the business sector SMEs in using the services of the accountant external.

4. Proven competencies has a positive effect on the intention of the owner of the business sector SMEs in using the services of the accountant external.

5. The size of the business proved a positive influence on the intention of the owner of the business sector SMEs in using the services of the accountant external.

6. Industry competitive proven positive effect on the intention of the owner of the business sector SMEs in using the services of the accountant external.

Theoretically, the results of this study have implications on the development of accounting behavioral, which in this research the factors of the Theory of Planned Behavior (TPB), namely attitude toward behavior, subjective norm, and perceived behavior control directly affects the intention of the individual, in previous research to affect individual's intention, which means that this study confirm that the Theory of Planned Behavior (TPB) can affect the individual's intention. The results of this study are expected to provide the impetus for SMEs to use the services of the accountant external as consideration in business continuity, as well as provide an overview to the government to provide the means and the socialization associated with the understanding the business owner of the SME sector regarding the importance of the need of the services of the accountant external in the world of business so that SMEs are able to compete with competitors in the market both national and global. In addition, the results of this research can be input for learning accounting behaviour.

This study still has some limitations, the limitations of this study is the sample of the study is limited only to SMEs trading in the City of Bengkulu, the results of this study explain that the attitude toward behavior, subjective norm, perceived behavioral control, the competence of the accountant external, the size of the business, and the competitive industry affect the intention of the owner of the business sector SMEs in using the services of the accountant external to $77 \%$ which means that there are still $33 \%$ is influenced by other variables outside the model of this study, most respondents of the study who is the owner of the business the SME sector does not control directly the activities of his business, so it is difficult to find, the suggestions for further research are expected of the respondents the research is not limited to SME trade, but should SMEs in other areas such as field services and manufacturing industries participated in the research, in order to consider other variables that may affect the intentions of the business owner of the SME sector in using the services of the accountant external, such as the socialization of the Financial Accounting Standards Entities Micro, Small and Medium enterprises, so consider the business managers who have the authority in the business once that control directly the activities of business so that it can be a respondent when the business owners of SMES are not at their place of business. 


\section{REFERENCES}

Abdillah, Willy dan Jogiyanto. 2015. Partial Least Square (PLS) - Alternatif Structural Equation Modeling (SEM) dalam Penelitian Bisnis. Yogyakarta. CV. Andi Offset.

Adawiyah, Wiwiek R. 2013. Faktor Penghambat Pertumbuhan Usaha Mikro Kecil Menengah (UMKM): Studi di Kabupaten Banyumas. Fakultas Ekonomi. Universitas Jendral Soedirman.

Agustiantono, Dwi. 2012. Analisis Faktor-Faktor Yang Mempengaruhi Kepatuhan Wajib Pajak Orang Pribadi: Aplikasi TPB. Semarang: Skripsi. Universitas Dipenogoro.

Ajzen, I. 1991. The Theory of Planned Behavior. Organizational Behavior and Human Decision Processes, 50 (2), 179-211.

I. 2005. Attitudes, Personality, and Behavior. Second Edition. England: Open University Press.

Aprilyan, Lara A. 2011. Faktor-Faktor yang Mempengaruhi Mahasiswa Akuntansi dalam Pemilihan Karir menjadi Akuntan Publik. Semarang: Skripsi. Universitas Diponegoro.

Asmarandani, Puteri L. 2017. Influence Attitude, Subjective Norms, Perceived Behavioral Control, Halal Certification, Religious Belief, Celebrity Endoser Terhadap Purchase Intention. Surabaya: Skripsi. Universitas Airlangga.

Bennett, R.J. \& Robson, P.J.A. 2005. The Advisor-SME Client Relationship: Impact. Satisfaction and Commitment. Small Business Economics. 25(3). pp. 255-271.

Blackburn, R. dan Jarvis, R. (2010). The Role of Small and Medium Practices In Providing Business Support To Small- And Medium-Sized Enterprises. A Report for the International Federation of Accountants (IFAC). ISBN: 978-1-60815-064-9: pp. 132. April 2010.

Carey, Peter J. G. T. 2016. The Provision of Business Advice to SMEs By External Accountants. Managerial Auditing Journal. Vol. 31. Iss 3 pp.-, 31 Januari 2016.

Chin, W. W. 1998. The Partial Least Squares Approach to Structural Equation Modeling. In G. A. Marcoulides (Ed.). Modern Methods for Business Research (295-336). Mahwah, New Jersey, London: Lawrence Eribaum Associates.

Cooper, Donald R., and Schindler, Pamela S. 2012. Business Research Methods, 12th ed. New York: McGraw-Hill.

Endah, Nur Hadiati. 2014. Perilaku Pembelian Kosmetik Berlabel Halal Oleh Konsumen Indonesia. Jurnal Ekonomi Pembangunan, 22(1), 11-25.

Engel, J.F., Blackell, R.D., and Miniard, P.W. 1993. Perilaku Konsumen: Edisi 6. Terjemahan oleh Budjianto. 1995. Jakarta: Binarupa Aksara.

Freciana, Melynda. 2013. Pengaruh Ekspresi Indentitas, Sikap, Norma Subjektif, Dan Control Perilaku Pada Niat Konsumen Untuk Membeli Produk Bajakan: Efek Moderasi Nilai Hedonis. Surabaya: Skripsi. Universitas Airlangga.

Ghazali, G. 2006. Structural Equation Modeling: Metode Alternatif dengan Partial Least Square. Semarang: Badan Penerbit Universitas Diponegoro.

Ghozali, Imam. 2014. Structural Equation Modeling Metode Alternatif dengan Partial Least Square: Edisi 4. Semarang: Badan Penerbit Universitas Diponegoro.

Gooderham P., Tobiassen A., Doving E., dan Nordhaug O. 2004. Accountants as Sources of Business Advice For Small Firms. International Small Business Journal. Vol. 22(1): pp. 5-22.

Instruksi Presiden Republik Indonesia Nomor 6 Tahun 2007 tentang Kebijakan Percepatan Pengembangan Sektor Riil Dan Pemberdayaan Usaha Mikro, Kecil, Dan Menengah. 2007. Jakarta

Jogiyanto, H. M. 2004. Metodologi Pemelitian Bisnis. Yogyakarta: BPFE -UGM.

Juliandi, Azuar, Irfan, dan Saprinal Manurung. 2014. Metodologi Penelitiam Bisnis, Konsep dan Aplikasi. Medan: UMSU PRESS. 
Kebijakan Pembiayaan Pertanian Tahun 2017 tentang Kinerja Penyaluran KUR 20062016. 2017. Ciawi. Kementerian Koordinator Bidang Perekonomian Republik Indonesia.

Kementerian Pendidikan Nasional. 2011. Standar Kompetensi Lulusan Akuntansi.

Keputusan Menteri Keuangan Republik Indonesia Nomor 43/ KMK.17/ 1997 tentang Jasa Akuntan Publik. 1996. Jakarta

Kuntjoroadi,W. dan Safitri, N. 2009. Analisis Strategi Bersaing dalam Persaingan Usaha Penerbangan Komersial, Bisnis \& Birokrasi. Jurnal Ilmu Administrasi dan Organisasi. Hlm. 45-52.

Laporan Hasil Pendataan Usaha Mikro Kecil Dan Menengah Tahun Anggaran 2016 Di Kota Bengkulu. 2016. Bengkulu: Dinas Koperasi Dan UMKM.

Lestari, Etty P. 2010. Penguatan Ekonomi Industri Kecil Dan Menengah Melalui Platform Klaster Industri. Jurnal Organisasi dan Manajemen, Vol. 6. No. 2. Hlm. 146- 157.

Lubis, Arfan.I. 2011. Akuntansi Keprilakuan: Edisi Kedua. Jakarta: Salemba Empat.

Muhardi. 2007. Strategi Operasi untuk Keunggulan Bersaing. Yogyakarta: Penerbit Graha Ilmu.

Mulya, Teuku A. 2009. Pengaruh Sikap, Norma Subjektif, Dan Perceived Behavioral Control Terhadap Intensi Menggunakan Transjakarta Untuk Pergi Ke Tempat Kerja. Depok: Skripsi. Universitas Indonesia.

Muntoro, K, Ronny. 2006. Profesionalisme Akuntan Manajemen. Economics Businness Accounting Review, II April 2006: Hlm: 101-112.

Murniati. 2002. Analisis Faktor-Faktor Yang Mempengaruhi Penyiapan Dan Penggunaan Informasi Akuntansi Pada Pengusaha Kecil Dan Menengah Di Jawa Tengah. Semarang: Tesis. Universitas Diponegoro.

Mustikasari, Elia. 2007. Kajian Empiris Tentang Kepatuhan Wajib Pajak Badan di Perusahaan Industri Pengolahan di Surabaya. Simposium Nasional Akuntansi X. Makasar.

Osa, Irfan K. 2010. Analisis Dampak Keberadaan LKM terhadap Perkembangan UMKM dan Penyebab Kendala Akses UMKM terhadap Lembaga Keuangan Formal. Bogor: Skripsi. Intitut Petanian Bogor.

Pitelis, Christos N. 2009. The Sustainable Competitive Advantage and Catching-Up of Nations: FDI, Clusters and The Liability (Asset) Of Smallness. Management International Review. Vol. 49. Issue 1. pp 95-120.

Polnaya, Ghalib A. 2015. Strategi Pengembangan Ekonomi Lokal Untuk Meningkatkan Daya Saing Pada Ukm Ekonomi Kreatif Batik Bakaran Di Pati, Jawa Tengah. Semarang: Skripsi. Universitas Dipenogoro.

Porter, Michael E. 1995. The Competitive Advantage of The Inner City. Harvard Businnes Review.

Rahmadanty, Cecia. 2015. Analisis Niat Perilaku Anggota Komunitas Hijabers Surabaya Dalam Menggunakan Tabungan Syariah. Jurnal Manajemen Teori dan Terapan. Vol.8. No.3. Desember 2015. Universitas Airlangga.

Ramahdaniati, Resti. 2017. Perilaku Berbagi Pengetahuan Akuntansi Pada Dosen Akuntansi Kota Bengkulu: Pendekatan Theory of Planned Behavior. Jurnal Akuntansi, Ekonomi, dan Manajemen Bisnis. Vol.5. No.1. Juli 2017. Universitas Bengkulu.

Raselawati, Ade. 2011. Pengaruh Perkembangan Usaha Kecil Menengah Terhadap Pertumbuhan Ekonomi Pada Sektor Ukm Di Indonesia. Jakarta: Skripsi. UIN Syarif Hidayatullah.

Robbins, Stephen.P. dan Judge, Timothy.A. 2007. Perilaku Organisasi: Edisi 12. Terjemahan oleh Diana Angelica. 2008. Jakarta: Salemba Empat.

Rois, Ekawati L. H. 2016. Pengaruh Religiusitas, Norma Subjektif, Dan Perceived Behavioural Control Terhadap Niat Membeli Produk Makanan Ringan Berlabel 
Halal. Jurnal Pendidikan dan Ekonomi. Vol. 4. No. 11. Tahun 2015. Universitas Negeri Yogyakarta.

Rudiantoro, Rizki dan Siregar, Sylvia V. 2012. Kualitas Laporan Keuangan UMKM Serta Prospek Implementasi SAK ETAP. Jurnal Akuntansi dan Keuangan Indonesia. Vol. 9 No. 1. Juni 2012 Universitas Indonesia.

Saputro, Temmy D. 2013. Pengaruh Profitabilitas, Umur Perusahaan, Tipe Perusahaan Dan Kepemilikan Manajerial Terhadap Kinerja Sosial Perusahaan Berdasarkan Iso 26000. Dipenogoro Journal of accounting. Vol. 3. No. 1. Tahun 2014.

Sarwono, Jonathan. 2007. Analisis Jalur Untuk Riset Bisnis: Aplikasi Riset Pemasaran, Keuangan, MSDM dan Kewirausahaan. Yogyakarta: Penerbit Andi.

Sekaran, Uma. 2006. Metodologi Penelitian untuk Bisnis Buku 1 dan 2 Edisi Pertama. Jakarta: Salemba Empat.

Setiadi, J. N. 2003. Perilaku Konsumen Dalam Konsep Dan Implikasi Untuk Strategi Penelitian Dan Pemasaran. Jakarta: Prenada Media.

Setiyani, Rediana. 2005. Faktor-Faktor Yang Membedakan Mahasiswa Akuntansi Dalam Memilih Profesi Sebagai Akuntan Publik Dan Non Publik. Semarang: Tesis. Universitas Dipenogoro.

Slameto. 2010. Belajar dan Faktor-faktor yang Mempengaruhinya. Jakarta: PT Rineka Cipta.

Sugiyono. 2012. Metode Penelitian Administrasi. Cetakan Ke-20. Bandung: Alfabeta.

Suryo, Anak. 2006. Akuntansi Untuk UKM: Metode Akuntansi Praktis Dan Sederhana Untuk Usaha Kecil Dan Menengah. Yogyakarta: Media Pressindo.

Susanti, Y. dan Gunarsih, T. 2008. Pengaruh Sikap Terhadap Perilaku, Faktor Sosial Dan Kontrol Keperilakuan Yang Dirasakan Terhadap Minat Pembelian Tiket Pesawat Secara Online. National Conference on Management Research.

Undang-Undang Republik Indonesia Nomor 20 Tahun 2008 tentang Usaha Mikro, Kecil, Dan Menengah. 2008.

Wahmuji. 2008. Kamus Besar Bahasa Indonesia Pusat Bahasa: Edisi Keempat. Jakarta. PT Gramedia Pustaka Utama.

Wicaksono, Arief L. 2015. Analisis Faktor-Faktor Yang Mempengaruhi Persepsi Pelaku Usaha Mikro Kecil Menengah Tentang Pentingnya Pelaporan Keuangan Berdasarkan Sak Etap. Artikel Ilmiah Mahasiswa. Tahun 2016.

Wiliams, S, Richard. 2002. Managing Employee Performance: Design and Implementation In Organizations. London: Thomson Learning.

Yamin, S. dan Kurniawan, H. 2009. Structural Equation Modeling: Belajar Lebih Mudah Teknik Analisis Data Kuesioner dengan LISREL-PLS, Buku Seri Kedua. Jakarta: Salemba Infotek.

Yogatama, L. A. M. 2013. Analisis Pengaruh Attitude, Subjective Norm, Dan Perceived Behavior Control Terhadap Intensi Penggunaan Helm Saat Mengendarai Motor Pada Remaja Dan Dewasa Muda di Jakarta Selatan. Prosiding PESAT, 5.

www.AntaraBengkulu.com: Empat Permasalahan Penyaluran KUR Di Kota Bengkulu. Kamis, 10 Agustus 2017.

www.jabar.metrotvnews.com: Wapres Luncurkan Standar Akuntansi Bagi UMKM. Kamis, 8 Desember 2016.

www.manajemenpraktis.com: Standar Akuntansi Keuangan EMKM efektif 1 Januari 2018. 28 September 2017. 